\title{
Modulation of UDP Glucuronosyltransferase 2B15 and 2B17 and Prostate Cancer Risk: Current Perspectives
}

\author{
Jasmin Thind, Carl Jenkinson, Declan P. Naughton and Andrea Petróczi
}

School of Life Sciences, Kingston University, London, United Kingdom

Correspondence should be addressed to: Andrea Petróczi; $\underline{A . P e t r o c z i @ k i n g s t o n . a c . u k ~}$

Received 18 December 2012; Accepted 31 January 2013; Published 17 March 2013

Academic Editor: Perihan Ünak

Copyright (C) 2013 Jasmin Thind, Carl Jenkinson, Declan P. Naughton and Andrea Petróczi. Distributed under Creative Commons CC-BY 3.0

\begin{abstract}
UDP glucuronosyltransferases (UGTs) are a family of enzymes that glucuronidate a variety of exogenous and endogenous compounds, including androgens; which makes them more hydrophilic, changes biological activity, and aids biological excretion. UGT2B17 has been identified as the major enzyme for testosterone glucuronidation, where UGT2B15 has been suggested to play a minor role. A deletion polymorphism in the UGT2B17 gene and an amino acid change in the UGT2B15 gene at codon 85 (aspartate>tyrosine) has been described where the resulting reduced rate of glucuronidation was implicated in the increased risk of prostate cancer. This review aims to analyse the impact that UGT2B15 and UGT2B17 genetic polymorphisms have on the risk of prostate cancer, through the use of studies previously conducted assessing the level of expression of each independent UGT2B enzyme, whereby ethnicity was taken into account. Positive and negative outcomes of clinical studies have been outlined for both UGT2B15 and UGT2B17, where conflicting evidence has led to inconclusive results for determining the consequence of UGT2B enzymes in prostate cancer risk. Additionally, inhibitors of testosterone glucuronidation such as non-steroidal, antiinflammatory drugs (diclofenac and ibuprofen), tea and red wine extracts have been identified to potentially affect the level of circulating testosterone by inhibiting UGT2B enzymes, thus potentially exacerbating prostate cancer risk. Future trials would involve a wider examination of other food substances and pharmaceuticals that can be attributed to the inhibition of UGT2B enzymes.
\end{abstract}

Keywords: Prostate Cancer, UDP-Glucuronosyltransferase, UGT2B15, UGT2B17.

\section{Introduction}

Prostate cancer $(P C a)$ is the most prominent malignancy in western countries formulating one eighth of all male-specific cancers (Park et al., 2006). It is estimated that $75 \%$ of all new PCa cases arise in developed countries (Park et al., 2007). According to Crawford (2003), PCa is more prevalent in people of an African

Cite this Article as: Jasmin Thind, Carl Jenkinson, Declan P. Naughton and Andrea Petróczi (2013), 
American background in comparison to any other ethnic minority. The incidence among African Americans is nearly 60\% higher than among whites.

The aetiology of PCa has yet to be identified; however, risk factors such as race, age, family history and steroid hormone levels have been suggested (Gronberg, 2003). Differing androgen levels have been recognised as a potential risk factor for $\mathrm{PCa}$, although results did not generate a coherent picture (Guillemette, 2003). The variation in androgen levels may be the outcome of differing activity or expression of the enzymes that are accountable for metabolism of androgens (Park et al., 2004; 2007).

The aim of this review is to summarise the available epidemiological evidence from the year 2000 onwards, regarding the association between UDP glucuronosyltransferase 2B15 (UGT2B15) and UDP glucuronosyltransferase 2B17 (UGT2B17) genetic polymorphisms and the risk of developing PCa. Additionally, the difference in the risk of developing PCa will be assessed in individuals of different ethnic backgrounds as well as the genotype expression of each independent enzyme in the prostate. Aside from genetic factors that predispose $\mathrm{PCa}$, external triggers will also be discussed as potential risk factors of PCa. Data evaluated in this review will be from both in vivo and in vitro studies.

Genetic polymorphisms are associated with a variety of genes that are responsible for coding enzymes that participate in the metabolic activity or detoxification of carcinogens (Erichsen et al., 2008). Polymorphic variants in androgen metabolising enzymes vary the level of androgens and thus affect the risk of developing PCa (Park et al., 2004; Wilson et al., 2004; Gallagher et al., 2007). UDP glucuronosyltransferase (UGT) enzymes are a super family of enzymes situated on the internal membrane of the endoplasmic reticulum (Gregory et al., 2004). UGTs participate in a catalytic glucuronidation reaction of a variety of endogenous and exogenous chemicals. In addition to these compounds, steroids, toxins and almost all classes of drugs are substrates for UGT enzymes (Guillemette, 2003). Glucuronidation is one of many fundamental phase 2 reactions also known as a conjugation reaction, which involves the transfer of co-substrate uridine diphospho-glucuronic acid (UDPGIcUA) to hydrophobic molecules. This results in the formation of $\beta$-D glucopyranosiduronic acid. The carboxyl group from the glucuronic acid which is ionized at physiological $\mathrm{pH}$ values promotes the excretion by increasing the aqueous solubility of the glucuronide, which is otherwise highly hydrophobic. The glucuronide is recognised by the bilary and renal organic anion transport systems, which enable excretion into urine and bile (Guillemette, 2003). Glucuronidation acts as a clearance mechanism and detoxification process for such glucuronide-conjugated molecules whereby the more polar, water soluble, less toxic molecules are more readily excreted from the body (Timbrell, 2000; Ritter, 2000; Miners et al., 2004).

\section{Expression and Metabolism of UGT2B Enzymes in the Prostate}

The UGT enzymes exist as subfamilies and are grouped on the basis of evolutionary divergence and the sequenced similarity between the subgroups (Gregory et al., 2004). The two most familiar groups of UGTs are UGT 1 and UGT 2, where most known UGTs belong to either the UGT 1A, $2 \mathrm{~A}$ or 2B sub-family (Mackenzie et al., 2005). Members of the UGT2B sub-family play a vital role in steroid metabolism to inactivate androgens (Turgeon et al., 2001). The enzymes are highly expressed in androgen-sensitive tissues such as the liver, kidney, skin, brain, breast, uterine and prostate (Turgeon et al., 2003). Two of them, UGT2B15 and UGT2B17 are expressed in the prostate which are concerned with the metabolism of androgenic steroids, such as testosterone, androsterone (ADT), androstane $-3 \alpha-17 \beta$ diol and dihydrotestosterone (DHT), which have been suggested to modify the risk of developing PCa (Bao et al., 2009). A study of human liver microsomes reported that UGT2B17 was expressed at some 4 fold higher in males with three fold higher activities (Gallagher et al., 2010). 
Testosterone, secreted by the testis, is necessary in order to maintain and develop growth of the prostate. Testosterone, either from circulation or from the adrenal precursors, is the main steroid hormone produced in the prostate; it is rapidly converted into DHT and its metabolites by $5 \alpha$-reductase activity. Testosterone is normally present in serum at a concentration approximately 10 times higher than that of DHT. However, in the prostate due to increased levels of $5 \alpha$ reductase activity, the proportion of testosterone present is decreased. Such analysis led to the assumption that prostate growth is closely related to the tissue concentration of DHT. Additionally, the adrenals secrete dehydroepiandrosterone (DHEA), its sulphate (DHEAS) and androsteredione into the circulation. The adrenal androgens are converted to testosterone and then to DHT and its metabolites by a $5 \alpha$-reduction (Barbier and Belanger, 2008).

In the human prostate, the alveoli form two types of epithelial cells: the basal and luminal cells. The two types of cells play an independent but complementary role in androgen formation and action (Barbier et al., 2000). The UGT2B17 isoform, expressed only in basal epithelial cells is concerned with the conversion of testosterone to DHT, which as a result, is metabolised to ADT and 3 $\alpha$-DIOL (Schleutker et al., 2011; Barbier et al., 2000). In contrast, the UGT2B15 isoform is expressed in luminal cells of the prostate where it is concerned with the inactivation of C19 steroid androgens, namely DHT (Olsson et al., 2008; MacLeod et al., 2000; Guillemette, 2003; Barbier et al., 2000). Although UGT2B17 shares more than 95\% homology with UGT2B15 (Turgeon et al., 2003; Barbier et al., 2000), the UGT2B17 isoform is found to be the major enzyme implicated in testosterone metabolism within the prostate where it has the highest capacity for both ADT and testosterone (Barbier and Belanger, 2008). Alternatively, UGT2B15 plays a diminutive role (Sten et al., 2009a). Thus, it can be postulated that the intracellular concentration of DHT and its respective metabolites in the prostate can be modulated by both UGT2B17 and
UGT2B15 in basal and luminal cells, respectively (Barbier et al., 2000).

According to Park et al., $(2004 ; 2006)$ the potential mechanism of carcinogenesis of prostate tissue involves the interaction of the androgen receptor when accompanied with DHT. The DNA present in proliferating prostate epithelial cell has the potential to produce permanent genomic mutations resulting in carcinogenic prostatic tissue (Erichsen et al., 2008). Moreover, as both UGT2B15 and UGT2B17 play a role in the degradation of DHT, it is suggested that it is the incomplete inactivation of testosterone conversion to DHT by UGT2B enzymes that may be associated with $\mathrm{PCa}$ risk, resulting from increased levels of DHT (Park et al., 2007).

\section{Modulation of UGT2B15 and UGT2B17 Enzymes and the Effect on Androgen Concentration and Activity in Prostate Cancer Lncap Cells}

The existence of UGT2B15/B17 in the epithelial cells of the human prostate has been clearly established, where the presence of androstane- $3 \alpha, 17 \beta$-diol ( $3 \alpha$ DIOL) and ADT-glucuronide concentrations were observed in this tissue (Chouinard et al., 2007). The human androgen-dependent cancer cell line (LNCaP), expresses UGT2B15/17 and is also competent in conjugating androgens. The impact of both genes in the inactivation of androgens in LNCaP cells was examined by using RNA interference to inhibit their expression (Barbier and Belanger, 2008). The results showed that the glucuronidation of DHT, $3 \alpha$-DIOL and ADT via LNCaP cell was decreased by more than $75 \%$ in UGT2B15/17 siRNA-transfected LNCaP cells in comparison to cells with a nontarget probe (Chouinard et al., 2007).

Moreover, the UGT2B15/B17-deficient LNCaP cells were observed to respond more strongly to DHT than in control cells, as exemplified by cell proliferation and presence of known androgen-sensitive genes. Upon evaluation, it is evident that both UGT2B15 and UGT2B17 are key enzymes for the local inactivation of androgens and that glucuronidation is 
critical for androgen action in prostate cells (Bao et al., 2009).

\section{Genetic Polymorphism of the UGT2B15 Gene and Deletion of the UGT2B17 Gene}

Polymorphisms associated with UGTs are suggested to influence steroid metabolism and cancer susceptibility (Lampe et al., 2000 ) as a result of a variation in the enzyme activity of the gene (Guillemette, 2003; Park et al., 2004). Polymorphic alleles have been identified in the coding region of the UGTB15 enzyme which results in an alteration at codon 85 from aspartate $\left(\mathrm{D}^{85}\right)$ to tyrosine (Y85) (Hajdinkjak and Zagradisnik, 2004; Mononen and Schleutker, 2009; Miners et al., 2002; Lampe et al., 2000; Gsur et al., 2002; Guillemette, 2003; Park et al., 2004). Additionally, it was postulated that a homozygous deletion polymorphism of the UGT2B17 enzyme significantly increases the risk of PCa as a consequence of reduced glucuronidation rates (Lazarus et al., 2005).

\section{UGT2B15 Genetic Polymorphism}

In a study by MacLeod et al. (2000), a $\mathrm{D}^{85}$ to $\mathrm{Y}^{85}$ polymorphism was identified in the UGT2B15 enzyme causing a 50\% reduction in enzyme activity. This study selected samples from different ethnic backgrounds where, according to Hajdinkjak and Zagradisnik (2004), selection may have only taken into account patients with poorly differentiated cancer, resulting in a poor reflection of the population as a whole. The UGT2B15 $\mathrm{D}^{85}$ allele is less proficient at glucuronidating DHT, and it is suggested that the presence of this low activity allele leads to higher intraprostatic DHT concentrations which is concerned with the increased risk of PCa (MacLeod et al., 2000; Park et al., 2004; Okugi et al., 2006; Barbier et al., 2000; Mononen and Schleutker, 2009; Miners et al., 2002). On this basis, people homozygous for the UGT2B15 $\mathrm{D}^{85}$ genotype have been suggested to be at a three-fold increased risk of developing PCa (MacLeod et al., 2000). Moreover, genotyping studies have revealed that the homozygous UGT2B15 $\mathrm{D}^{85}$ allele is more prevalent in individuals with PCa, where higher levels of DHT were implicated with PCa development (MacLeod et al., 2000; Park et al., 2004; Miners et al., 2002). The identification of the high-risk D/D genotype by Okugi et al. (2006) reinforces the association of this genotype and correlation with PCa. Hajdinkjak and Zagradisnik (2004) similarly highlight the significance of the D/D genotype frequency between the differentiated groups (OR=2.04, 95\% $\mathrm{CI}=1 \cdot 10-3.79$ ).

Although UGT2B15 $\mathrm{D}^{85}$ and UGT2B15 $\mathrm{Y}^{85}$ have similar substrate specificities, the UGT2B15 $\mathrm{Y}^{85}$ allele was reported to have a two-fold higher Vmax than UGT2B15 D85 for C19 steroids (Okugi et al., 2006; Mononen and Schleutker, 2009; Lampe et al., 2000; Hajdinkjak and Zagradisnik, 2004; Turgeon et al., 2001), where the lower enzyme activity has the potential to increase the amount of DHT in prostate tissue as well as to increase exposure to androgens and possibly also increase the risk of PCa (Hajdinkjak and Zagradisnik, 2004). In contrast, Barbier and Belanger (2008) suggested the high efficacy of the Y85 enzyme may serve to protect the prostate from increased levels of DHT and consequently decrease the risk.

Furthermore, there is evidence to suggest that genotype distributions vary by ethnic groups. In one study by Lampe et al., (2000), the $Y^{85}$ allele was more prevalent among Caucasians than Asians (32\% vs. $18 \%$, respectively). Therefore, we may postulate that PCa risk can also vary according to ethnicity. Additionally, studies have been identified in which the $\mathrm{D}^{85} \mathrm{Y}$ polymorphism was not associated with risk of developing PCa. A study by Gsur et al. (2002) revealed insignificant differences between cases and controls (UGT2B15 $\mathrm{Y}^{85} / \mathrm{Y}^{85}$ genotype frequency for $\mathrm{PCa}$ cases and controls was $27 \%$ and $26 \%$, respectively with an OR, 95\% CI; 1.20). However, according to Wilson et al. (2004) the incorporation of recipients with benign prostatic hyperplasia may have negatively influenced the association. In accordance with the negative results outlined by Gsur et al. (2002), Hajdinkjak and Zagradisnik (2004) also found no correlation between PCa cases and controls. However, according 
to Hajdinkjak and Zagradisnik (2004), the previous study (Gsur et al., 2002) failed to select a control group that reflected the frequency of alleles in the general population, perhaps confounding the final result.

Although the UGT2B15 allele plays a key role in conjugation and secretion of steroid hormones in the prostate, based on the conflicting evidence above it remains undecided if the UGT2B15 (D ${ }^{85}$ Y) polymorphism can be outlined as a marker for the risk of PCa (Table 1).

\section{Ugt2b17 Deletion Polymorphism}

Like UGT2B15, the UGT2B17 isoform is significantly associated with its active role in androgen glucuronidation (Gallagher et al., 2007; Chouinard et al., 2007; Turgeon et al., 2001; Barbier et al., 2000). The inter- individual variations of androgen inactivating enzyme activity may be implicated with the risk of developing PCa, as those with diminished enzyme activity were suggested to incur lower androgen levels in comparison to those who maintain normal activity (Schatzl et al., 2003). In contrast, Gallagher et al. (2007) and Park et al. (2007) claim that it is increased serum androgen levels that are associated with such risk. Genetic polymorphisms identified in UGT2B androgen metabolising enzymes were suggested to impact the level of enzymatic activity as well as expression (Park et al., 2006; Wilson et al., 2004; Gallagher et al., 2007). An entire polymorphic gene deletion of the UGT2B17 enzyme was indicated to cause a decrease in the glucuronidation activity (Lazarus et al., 2005), where a homozygous UGT2B17 gene deletion was implicated to be in risk of developing PCa (Gallagher et al., 2007).

\section{Table 1. Summary of in Vitro and in Vivo Clinical Studies that Show the UGT2B15 Genetic Polymorphism and the Risk of Prostate Cancer}

\begin{tabular}{|c|c|c|c|c|}
\hline Clinical Study & Sample ${ }^{a}$ & $\begin{array}{c}\text { Number of } \\
\text { cases/contro } \\
\text { ls }\end{array}$ & $\begin{array}{c}\text { Positive }^{b} \\
\text { or } \\
\text { Negativec }^{c} \\
\text { outcome }\end{array}$ & Findings \\
\hline $\begin{array}{l}\text { ASP85TYR polymorphism in } \\
\text { the UDP- } \\
\text { glucuronosyltransferase } \\
\text { (UGT) 2B15 gene and the risk } \\
\text { of prostate cancer } \\
\text { (Park et al., 2004) }\end{array}$ & $\begin{array}{l}\text { White } \\
\text { Males }\end{array}$ & $155 / 155$ & + & $\begin{array}{l}\text { The UGT2B15 D85 allele exhibited a twofold decrease } \\
\text { for DHT, which was indicated association with an } \\
\text { increased risk of PCa } \\
\text { UGT2B15 mRNA was found in all prostate tissues } \\
\text { tested. } \\
\text { An increased risk of PCad was established in subjects } \\
\text { with the homozygous UGT2B15 } \\
\text { D85 genotype. }\end{array}$ \\
\hline $\begin{array}{l}\text { An Allele-Specific Polymerase } \\
\text { Chain Reaction Method for } \\
\text { the Determination of the } \\
\text { D85Y Polymorphism in the } \\
\text { Human UDP } \\
\text { Glucuronosyltransferase } \\
\text { 2B15 Gene in a Case-Control } \\
\text { Study of Prostate Cancer } \\
\text { (MacLeod et al., 2000) }\end{array}$ & Males & $64 / 64$ & + & $\begin{array}{l}\text { The distribution of the UGT2B15 polymorphism was } \\
\text { examined in a small case-control group. } \\
\text { The } \mathrm{D}^{85} \text { to } \mathrm{Y}^{85} \text { polymorphism was recognized where a } \\
50 \% \text { reduction in enzyme activity was found. } \\
\text { PCa patients were found to be homozygous for the } \\
\text { lower activity allele } \mathrm{D}^{85} \text { UGT2B15 allele in } \\
\text { comparison to control individuals ( } 41 \% \text { versus } 19 \%) \text {, } \\
\text { respectively. } \\
\text { Increased risk of developing cancer in patients } \\
\text { homozygous for the D } \mathrm{D}^{85} \text { low-activity allele was } \\
\text { threefold higher. }\end{array}$ \\
\hline $\begin{array}{l}\text { Association of the } \\
\text { polymorphisms of genes } \\
\text { involved in androgen } \\
\text { metabolism and signalling } \\
\text { pathways with familial } \\
\text { prostate cancer risk in a } \\
\text { Japanese population } \\
\text { (Okugi et al., 2006) }\end{array}$ & $\begin{array}{c}\text { Japanese } \\
\text { Males }\end{array}$ & $102 / 117$ & + & $\begin{array}{l}\text { Single polymorphisms with the existence of Y alleles } \\
\text { showed a significantly lower risk of prostate cancer } \\
\text { when compared to the D/D UGT2B15 genotype. } \\
\text { The Y85 isoform was also found to be twice as } \\
\text { efficient as the D85 in conjugating 3-DIOL and DHT. }\end{array}$ \\
\hline
\end{tabular}




\begin{tabular}{|c|c|c|c|c|}
\hline $\begin{array}{l}\text { Genetic polymorphisms of } \\
\text { UDP- } \\
\text { glucuronosyltransferases and } \\
\text { their functional significance } \\
\text { (Miners et al., 2002) }\end{array}$ & $\begin{array}{c}\text { Caucasian } \\
\text { Males }\end{array}$ & 27 subjects & $\mathrm{N} / \mathrm{A}^{\mathrm{d}}$ & $\begin{array}{l}\text { The study stated that the Vmax for DHT } \\
\text { glucuronidation by the Asp } 85 \text { allele is reduced when } \\
\text { compared to that for the Tyr85 allele. } \\
\text { Those with the homozygous ASP85 allele were } \\
\text { suggested to have increased androgen exposure. }\end{array}$ \\
\hline $\begin{array}{l}\text { A polymorphism in the UDP- } \\
\text { Glucuronosyltransferase } \\
\text { 2B15 Gene (D } 85 \text { Y) Is Not } \\
\text { Associated with Prostate } \\
\text { Cancer Risk } \\
\text { (Gsur et al., 2002) }\end{array}$ & $\begin{array}{l}\text { Caucasian } \\
\text { Males }\end{array}$ & $190 / 190$ & - & 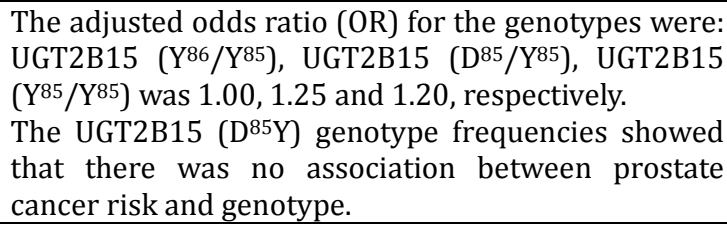 \\
\hline $\begin{array}{l}\text { Prostate cancer and } \\
\text { polymorphism D85Y in gene } \\
\text { for dihydrotestosterone } \\
\text { degrading enzyme UGT2B15: } \\
\text { Frequency of DD } \\
\text { homozygotes increases with } \\
\text { gleason score } \\
\text { (Hajdinjak T and Zagradisnik } \\
\text { B, 2004) }\end{array}$ & Males & $206 / 178$ & N/A & $\begin{array}{l}\text { Gleason scores were genotyped which enabled the } \\
\text { recognition of both alleles in an individual. Controls: } \\
16 \% \text { DD; } 52 \% \text { DY; Prostate cancer patients: } 23 \% \text { DD, } \\
49 \% \text { DY. Subgroups of prostate cancer: well } \\
\text { differentiated: } 11 \% \text { DD, } 37 \% \text { DY; moderately } \\
\text { differentiated: } 22 \% \text { DD, } 50 \% \text { DY; Poorly } \\
\text { differentiated: } 34 \% \text { DD, } 50 \% \text { DY. } \\
\text { The difference in frequency of DD was significant } \\
\text { among the groups. D85Y polymorphism in UGT2B15 } \\
\text { corresponds with differentiation of prostate cancer. }\end{array}$ \\
\hline $\begin{array}{l}\text { Evaluation of genetic } \\
\text { variations in the androgen } \\
\text { and estrogen metabolic } \\
\text { pathways as risk factors for } \\
\text { sporadic and familial prostate } \\
\text { cancer } \\
\text { (Cunningham et al., 2007) }\end{array}$ & Males & $499 / 493$ & - & $\begin{array}{l}\text { The results in the study were not significant for the } \\
\text { Try85Asp polymorphism, adjusted } p \text { values for } \\
\text { multiple comparisons for sporadic prostate cancer } \\
\text { cases versus control was } 1.00 \text {. }\end{array}$ \\
\hline $\begin{array}{l}\text { Relative enzymatic activity, } \\
\text { protein stability and tissue } \\
\text { distribution of human steroid } \\
\text { metabolizing UGT2B } \\
\text { subfamily members } \\
\text { (Turgeon et al., 2001) }\end{array}$ & $\begin{array}{l}\text { HK293 } \\
\text { Cell Line }\end{array}$ & $\mathrm{N} / \mathrm{A}$ & N/A & $\begin{array}{l}\text { There was a twofold higher glucuronidation rate of } \\
\text { the UGT2B15 }\left(\mathrm{Y}^{85}\right) \text { allele compared to the UGT2B15 } \\
\text { (D85) allele. } \\
\text { UGT2B15 was shown to have a low activity towards } \\
\text { testosterone and a higher activity towards DHT. } \\
\text { The study demonstrates the relative activities and } \\
\text { major substrates of human steroid-metabolizing } \\
\text { UGT2B15 and UGT2B17 enzymes expressed in a } \\
\text { wide variety of steroid target tissue }\end{array}$ \\
\hline $\begin{array}{l}\text { Cellular localization of } \\
\text { uridine } \\
\text { diphosphoglucuronosyltrans- } \\
\text { ferase 2B enzymes in the } \\
\text { human prostate by in situ } \\
\text { hybridization and } \\
\text { immunochemistry } \\
\text { (Barbier et al., 2000) }\end{array}$ & $\begin{array}{l}\text { Epithelial } \\
\text { Cells }\end{array}$ & $\mathrm{N} / \mathrm{A}$ & $\mathrm{N} / \mathrm{A}$ & $\begin{array}{l}\text { The UGT2B15D } 85 \text { enzyme was found to be less } \\
\text { efficient in glucuronidating DHT, therefore it was } \\
\text { proposed that the presence of the low activity allele } \\
\text { would result in higher intraprostatic DHT } \\
\text { concentration }\end{array}$ \\
\hline
\end{tabular}

a Sample refers to either a particular ethnicity being analysed or to a certain cell line

${ }^{\mathrm{b}}$ A positive clinical study is where the results indicate a clear association between Prostate Cancer risk and UGT2B15 Genetic Polymorphism

${ }^{\mathrm{c}} \mathrm{A}$ negative clinical study is where the results establish no correlation between Prostate Cancer risk and UGT2B15 Genetic Polymorphism

${ }^{\mathrm{d}} \mathrm{N} / \mathrm{A}=$ Not Applicable. The sub-heading of the column cannot be applied to the clinical study as the results of the study have not outlined conclusive results, or the nature of the study does not allow them to be applied, i.e. cell culture studies will not have cases or controls

Park et al. (2006) examined the prevalence of the UGT2B17 deletion polymorphism in Caucasians and African Americans with propensity to PCa risk. A strong association between UGT2B17 deletion polymorphism and the incidence of PCa was established. Stratified analysis by ethnicity exposed an increase in PCa risk amongst Caucasians with UGT2B17 deletion polymorphism, whereas the risk for African Americans 
remained statistically insignificant (Table $2)$. However, based on this study it is unjustified to assume that those of the African American background are not susceptible to PCa. Additional population based studies in men of African American background would need to be carried out, where only by obtaining similar statistically insignificant results would a generalisation regarding the risk of PCa be of validity.

According to Lampe et al. (2000), polymorphisms often show distinctive population differences which result in different distributions amongst various ethnic groups. Wilson et al. (2004) demonstrated that the absence of the UGT2B17 gene is five times more frequent in Caucasians than in African Americans; $11 \%$ and $2 \%$, respectively. The occurrence of the del/del genotype was also $11 \%$ with formerly reported genotype distribution amongst Caucasians (Park et al., 2006; Gallagher et al., 2007; Olsson et al., 2008). In addition, Jakobbson et al. (2006) demonstrated the UGT2B17 del/del polymorphism to be seven times more prevalent in the Korean $(66.7 \%)$ than the Swedish population (9.3\%), where Terakura et al. (2005) also reported higher prevalence among Asian men. The difference in genotype frequencies amongst the populations can be used to assume that the risk of $\mathrm{PCa}$ varies between ethnic minorities.

Table 2. Summary of in Vivo Clinical Studies that Show the UGT2B17 Genetic Polymorphism and the Risk of Prostate Cancer

\begin{tabular}{|c|c|c|c|c|}
\hline Clinical Study & Samplea & $\begin{array}{c}\text { Number of } \\
\text { cases/contro } \\
\text { ls }\end{array}$ & $\begin{array}{c}\text { Positive } \\
\text { Or } \\
\text { Negative }^{\text {c }} \\
\text { outcome }\end{array}$ & Findings \\
\hline $\begin{array}{l}\text { The UGT2B17 gene } \\
\text { deletion } \\
\text { polymorphism and } \\
\text { risk of prostate } \\
\text { cancer: } \\
\text { A case-control study } \\
\text { in Caucasians } \\
\text { (Gallagher et al., } \\
\text { 2007) }\end{array}$ & Caucasian Males & $411 / 397$ & 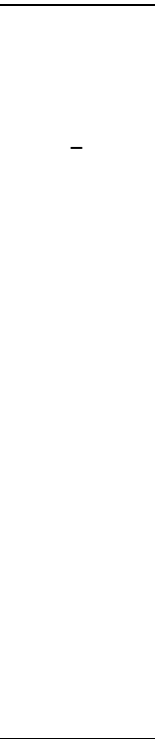 & $\begin{array}{l}\text { Using a novel real time PCR } \\
\text { method was employed to } \\
\text { differentiate between } \\
\text { heterozygous (+/0) and } \\
\text { homozygous (+/+) UGT2B17 } \\
\text { genotypes. } \\
\text { The study illustrated no } \\
\text { distinctive difference in the } \\
\text { occurrence of the UGT2B17 } \\
\text { deletion genotype (O/O) amongst } \\
\text { prostate cancer cases }(10 \%) \text { and } \\
\text { controls }(12 \%) \text { Inconsistency in } \\
\text { results may have arisen from a } \\
\text { down-regulation of UGT2B17 } \\
\text { transcription via androgens which } \\
\text { are not modulated by androgens. } \\
\text { The study found deletion of } \\
\text { UGT2B17 to have little effect on } \\
\text { glucuronidation rates and thus } \\
\text { little impact on risk of PCa. }\end{array}$ \\
\hline $\begin{array}{l}\text { The UGT2B17 gene } \\
\text { deletion is not } \\
\text { associated with } \\
\text { prostate cancer risk } \\
\text { (Olsson et al., 2008) }\end{array}$ & Swedish Males & $3,161 / 2,149$ & - & $\begin{array}{l}\text { A cancer of the prostate Sweden } \\
\text { (CAPS) population-based case- } \\
\text { control study. } \\
\text { A genotyping analysis which } \\
\text { comprised of a 5o-nuclease } \\
\text { activity assay was used to } \\
\text { establish those with either one or } \\
\text { two gene copies (ins/ins or } \\
\text { ins/del) from individuals } \\
\text { homozygous for the deletion } \\
\text { (del/del) allele. } \\
\text { The study found no significant } \\
\text { association between the incidence }\end{array}$ \\
\hline
\end{tabular}




\begin{tabular}{|c|c|c|c|c|}
\hline & & & & $\begin{array}{l}\text { of prostate cancer and deletion of } \\
\text { the UGT2B17 gene for individuals } \\
\text { who are UGT2B17 del/del } \\
\text { carriers. }\left(\mathrm{OR}^{\mathrm{d}}=1.01,95 \% \text { CI } 0.83 \text { - }\right. \\
1.23) \text {. }\end{array}$ \\
\hline $\begin{array}{l}\text { Association Between } \\
\text { Polymorphisms in } \\
\text { HSD3B1 and } \\
\text { UGT2B17 and } \\
\text { Prostate Cancer Risk } \\
\text { (Park et al., 2007) } \\
\end{array}$ & $\begin{array}{l}\text { White and African } \\
\text { Americans Males }\end{array}$ & $356 / 363$ & + & $\begin{array}{l}\text { A significant association was } \\
\text { found between the UGT2B17 null } \\
\text { polymorphism and prostate } \\
\text { cancer (OR=3.0, } 95 \% \text { CI } 1.0-9.2 \text { ). }\end{array}$ \\
\hline $\begin{array}{l}\text { Characterization of a } \\
\text { common deletion } \\
\text { polymorphism of the } \\
\text { UGT2B17 gene linked } \\
\text { to UGT2B15 } \\
\text { (Wilson et al., 2004) }\end{array}$ & $\begin{array}{c}\text { Caucasians and } \\
\text { African Americans } \\
\text { Males }\end{array}$ & $\begin{array}{l}85 \quad \text { African } \\
\text { Americans } \\
\text { and } 103 \\
\text { Caucasians }\end{array}$ & $\mathrm{N} / \mathrm{A}^{\mathrm{e}}$ & $\begin{array}{l}\text { The study screened participants } \\
\text { for markers C and J, which } \\
\text { specifically recognised the } \\
\text { presence or absence of the } \\
\text { UGT2B17 gene. } \\
\text { DNA spanning the UGT2B17 gene } \\
\text { is absent in } 9 \text { out of the } 40 \text { human } \\
\text { DNA samples, while all samples } \\
\text { contained the UGT2B15 gene. } \\
\text { The absence of the UGT2B17 gene } \\
\text { was more prevalent in Caucasians } \\
\text { than African Americans (11\% and } \\
\text { 2\%, respectively). }\end{array}$ \\
\hline $\begin{array}{l}\text { Deletion } \\
\text { Polymorphism of } \\
\text { UDP- } \\
\text { Glucuronosyltransfera } \\
\text { se } 2 \text { B17 and Risk of } \\
\text { Prostate Cancer in } \\
\text { African American and } \\
\text { Caucasian Men } \\
\text { (Park et al., 2006) }\end{array}$ & $\begin{array}{c}\text { Caucasians and } \\
\text { African Americans } \\
\text { Males }\end{array}$ & $420 / 487$ & + & $\begin{array}{l}\text { The frequency of UGT2B17 } \\
\text { distribution amid the Caucasian } \\
\text { and African American ethnicities } \\
\text { was } 11 \% \text { and } 12 \% \text {, respectively. } \\
\text { An OR, of } 1.7 ; 95 \% \text { CI, } 1.2-2.5 \\
\text { suggested an increased risk of } \\
\text { prostate cancer for individuals } \\
\text { with at least one UGTB17 allele. } \\
\text { An increased risk of prostate } \\
\text { cancer was observed amid } \\
\text { Caucasian individuals with an OR, } \\
\text { of } 1.8 ; 95 \% \text { CI, } 1.2-2.8 \text {. } \\
\text { The risk of prostate cancer among } \\
\text { African Americans remained } \\
\text { statistically insignificant with an } \\
\text { OR, of } 1.5 ; 95 \% \text { CI, } 0.7-3.1 \text {. }\end{array}$ \\
\hline $\begin{array}{l}\text { A UGT2B17-positive } \\
\text { donor is a risk factor } \\
\text { for higher transplant- } \\
\text { related mortality and } \\
\text { lower survival after } \\
\text { bone marrow } \\
\text { transplantation } \\
\text { (Terakura et al., 2005) }\end{array}$ & Japanese Males & 435 Subjects & N/A & $\begin{array}{l}\text { Homozygous UGT2B17 deletion } \\
\text { was observed in } 85 \% \text { of normal } \\
\text { Japanese donors, which was found } \\
\text { to be higher than that (11\%) } \\
\text { observed in normal White donors. }\end{array}$ \\
\hline $\begin{array}{l}\text { Deletion } \\
\text { polymorphism of the } \\
\text { UGT2B17 gene is } \\
\text { associated with } \\
\text { increased risk of } \\
\text { prostate cancer and } \\
\text { correlated to gene } \\
\text { expression in the } \\
\text { prostate } \\
\text { (Karypidis et al., } \\
\text { 2008) }\end{array}$ & Swedish Males & $176 / 161$ & + & $\begin{array}{l}\text { The study found that individuals } \\
\text { homozygous for the insertion } \\
\text { allele expressed } 30 \text { times more } \\
\text { UGT2B17 mRNA in prostate tissue } \\
\text { than the heterozygote's } \\
\text { Carriers of the deletion had a } \\
\text { significant increase in the risk of } \\
\text { prostate cancer (OR=2.07; } \\
95 \% \text { CI=1.32-3.35). } \\
\text { The study concluded that the } \\
\text { UGT2B17 deletion polymorphism }\end{array}$ \\
\hline
\end{tabular}




\begin{tabular}{|c|c|c|c|c|}
\hline & & & & $\begin{array}{l}\text { is associated with risk of prostate } \\
\text { cancer. }\end{array}$ \\
\hline $\begin{array}{l}\text { Large Differences in } \\
\text { Testosterone } \\
\text { Excretion in Korean } \\
\text { and Swedish Men are } \\
\text { Strongly Associated } \\
\text { with a UDP- } \\
\text { Glucuronosyl } \\
\text { Transferase 2B17 } \\
\text { Polymorphism } \\
\text { (Jakobsson et al., } \\
\text { 2006) }\end{array}$ & $\begin{array}{l}\text { Swedish and } \\
\text { Korean Males }\end{array}$ & $\begin{array}{lr}122 & \text { Swedes } \\
\text { and } & 74 \\
\text { Koreans } & \end{array}$ & $\mathrm{N} / \mathrm{A}$ & $\begin{array}{l}\text { Urine from subjects was analyzed } \\
\text { for several androgen } \\
\text { glucuronides, } \\
\text { testosterone. } \\
\text { When the UGT2B17 genotypes } \\
\text { were compared with urinary } \\
\text { testosterone levels, all of the } \\
\text { individuals of the UGT2B17 } \\
\text { homozygous deletion/deletion } \\
\text { genotype had little or negligible } \\
\text { amounts of urinary testosterone. } \\
\text { The deletion/deletion genotype } \\
\text { was seven times more prevalent } \\
\text { in the Korean (66.7\%) than the } \\
\text { Swedish population }(9.3 \%) \text {. }\end{array}$ \\
\hline
\end{tabular}

${ }^{\mathrm{b}} \mathrm{A}$ positive clinical study is where the results indicate a clear association between Prostate Cancer risk and UGT2B15 Genetic Polymorphism

c A negative clinical study is where the results establish no correlation between Prostate Cancer risk and UGT2B15 Genetic Polymorphism

d $\mathrm{OR}=$ odds ratio; $\mathrm{CI}=$ Confidence Interval

e N/A= Not Applicable. The sub-heading of the column cannot be applied to the clinical study as the results of the study have not outlined conclusive results or the nature of the study does not allow them to be applied, i.e. cell culture studies will not have cases or controls 
Although the variation in the distribution of the UGT2B17 deletion polymorphism has been established, the results have not been consistent. For instance, the genotype distribution for African Americans in the study conducted by Park et al. (2006) was $11 \%$, where Wilson et al. (2004) demonstrated an occurrence of a mere $2 \%$. Such differences observed illustrate that UGT2B17 genotype frequency has the potential to vary in different regions of the United States. However, it also reinforces the need for additional studies to be conducted in order to confirm any potential trends which may lead to conclusive results regarding the risk of $\mathrm{PCa}$ amongst different ethnic minorities. Based on the findings of Wilson et al. (2004) and Park et al. (2006), it can be posited that Caucasians are at a greater risk of developing PCa when compared to the African American population in the studies. However, this generalisation from limited studies cannot be applied to the Caucasian population as a whole; as additional studies would need to confirm the greater risk of PCa in Caucasian males and in contrast to other ethnic groups.

A study carried out by Jakobsson et al. (2006) examined the effect of the UGT2B17 deletion polymorphism on the distribution and excretion of urinary testosterone. It was maintained that the deletion of the UGT2B17 gene is linked with low or negligible amounts of urinary testosterone, reiterating the importance of the enzyme for testosterone glucuronidation. Additionally, it was found that individuals who exhibit the del/del genotype undergo decreased levels of testosterone glucuronidation. PCa risk was previously implicated with reduced testosterone glucuronidation (Park et al., 2006), thus it can be assumed individuals who display the del/del genotype are at an increased risk. In contrast, other studies have shown the lack of association between UGT2B17 deletion polymorphism and PCa risk (Table 2).

In summary, there appears to be contradictory evidence surrounding the role of the UGT2B17 deletion polymorphism in PCa risk. Multiple studies that examine the role of the glucuronidating enzyme are required in order to produce conclusive results. Table 2 outlines in further detail the studies already discussed, as well as additional studies examining the UGT2B17 deletion polymorphism and risk of $\mathrm{PCa}$. Both UGT2B15 and UGT2B17 bind testosterone and metabolites of 5- $\alpha$ reductase, where expression in steroid target tissues such as the prostate suggests a function in $\mathrm{PCa}$ (Wilson et al., 2004). Although both UGT2B15 and UGT2B17 have been identified with different genetic polymorphisms; they are both considered to be important in human liver microsomal (HLM) testosterone glucuronidation (Bowalgaha et al., 2007), where clinical studies have shown the two enzymes to independently effect intra-prostatic levels of DHT.

\section{Factors Influencing the Metabolic Functions of UGT2B15 and UGT2B17}

To further examine the consequence of UGT2B15 and UGT2B17 genetic polymorphism and the risk of $\mathrm{PCa}$, it is important to identify other potential risk factors, such as diet, lifestyle and additional drugs that could impact the metabolism of such enzymes. Reduction in testosterone glucuronidation via the inhibition of UGT2B enzymes has been associated with elevated levels of circulating testosterone (Jacobsson et al., 2006; Sten et al., 2009b; Jenkinson et al., 2012a, 2012b), which was previously implicated in PCa risk (Park et al., 2007). Notably, UGT2B15 and UGT2B17 do not glucuronidate epitestosterone which are metabolised by alternate UGT enzymes (Sten et al., 2009a). Indeed, epitestosterone acts as a competitive inhibitor against UGT2B17, implicating a role for the known variations in epitetosterone levels in controlling testosterone concentrations (Sten et al., 2009a). However, further studies are warranted in this area as levels of epitestosterone that effected inhibition are considerably higher than those found in vivo (Havlikova et al., 2002). 


\section{Non-Steroidal Anti-Inflammatory Drugs (NSAIDS) Possibly Associated with Increased Risk}

NSAIDs, such as ibuprofen and diclofenac, are commonly used drugs used in the prophylaxis of pain and inflammation and are metabolised by UGTs through glucuronidation. Both steroids and NSAIDs are substrates for UGT enzymes and it has been revealed that diclofenac and ibuprofen competitively inhibit UGT2B15 and UGT2B17 potentialy resulting in a reduced testosterone glucuronidation rate with an $\mathrm{IC}_{50}$ value for diclofenac inhibition of 64 ? M, and 213 ? $\mathrm{M}$ for ibuprofen (Sten et al., 2009b). UGT2B15 was more sensitive than UGT2B17 to the two drugs, particularly to ibuprofen (Sten et al., 2009b). Moreover, an increased sensitivity to ibuprofen signified that UGT2B15 is mostly responsible for testosterone glucuronidation in UGT2B17- deficient individuals. The inhibitory efficacy of ibuprofen was found to be reliant on the UGT2B17 genotype, where higher inhibition was illustrated in recipients with the del/del genotype compared to those with ins/ins and ins/del (Sten et al., 2009b). However, these results are for in vitro studies which have yet to be repeated in vivo.

Therefore, based on the inhibitory efficacy of both diclofenac and ibuprofen for HLM testosterone glucuronidation, the researchers can speculate that individuals who exhibit the UGT2B17 del/del polymorphism may be at a greater risk of developing $\mathrm{PCa}$, as a result of the higher NSAID inhibition demonstrated in del/del subjects. However, the potential risk of PCa would only apply to those patients who are taking NSAIDs as a long-term prophylaxis. In order to evaluate the practical repercussions of such findings, future investigations are warranted to be conducted in vivo, where studies to examine the inhibitory effect of NSAIDs as well as UGT2B enzymes could be carried out. It would also be an advantage for future studies to be done in the context of PCa susceptibility to see if similar results could be obtained to the previous study by Sten et al. (2009b).

\section{Diet and Risk of Prostate Cancer}

To date, many studies have identified the effect of UGT2B genetic polymorphisms on the incidence of PCa risk. However, little has been investigated about the effect diet has on such UGT2B enzymes (Wolk, 2005). This is despite the numerous studies that testify to the high rate of self-medication with herbal and dietary supplements, particularly among cancer patients (Neuhouser and Rock, 2010). Although observational studies across cultures suggest that some dietary components and associated nutrients may have an effect on PCa risk (Lewis et al., 2009; Brasky et al., 2011; Ma and Chapman, 2009), caution is advised in promoting dietary supplements for said purpose, whilst concerns have been raised over potential herbal-drug interaction (Eichorn et al., 2011). Amongst the dietary components with putative prostate cancer preventive, teas (particularly green teas) received increased attention, but evidence for cancer preventive effects of dietary flavonoids such as those found in green tea is inconclusive (Boehm et al., 2009).

Dietary components such as flavonoids found in foods, such as fruits and vegetables have been suggested to have the ability to act as cancer preventative agents (Moon et al., 2006). Wolk (2005) suggested that diet plays a significant role in the initiation, promotion and progression of PCa. 


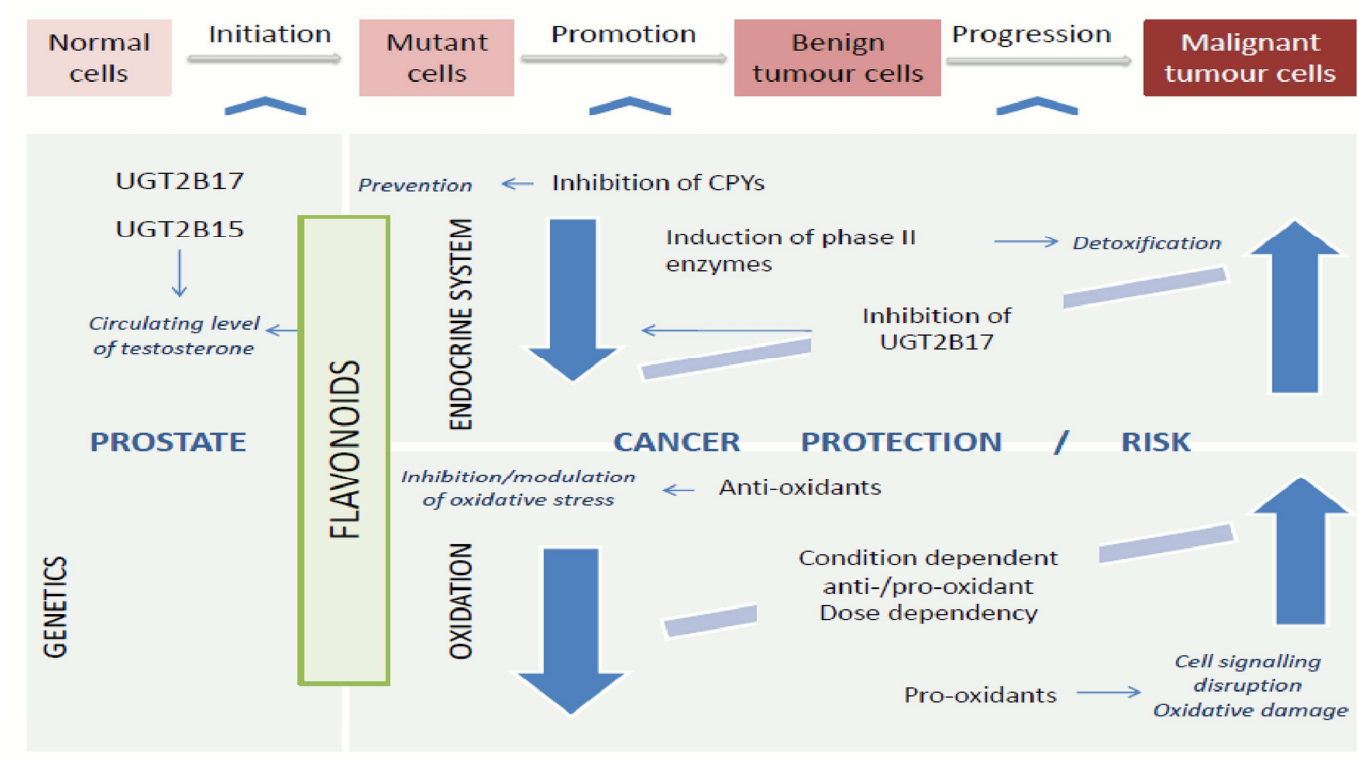

Figure 1: Multiple roles of flavonoids in the initiation and progression of stages of cancer development: UGT inhibition may affect toxin and endocrine levels including testosterone; while amelioration or augmentation of oxidative damage may occur in a dose dependent manner [adapted from Moon et al., 2006].

Figure 1 illustrates the stages at which dietary flavonoids are able to effectively block or suppress progression to carcinogenesis. Such flavonoids initiate the detoxification of carcinogens via the induction of phase 2 enzymes, resulting in their elimination from the body (Moon et al., 2006).

Advancing on this, a recent study by Jenkinson et al. (2012a) demonstrated that testosterone glucuronidation was inhibited by green and white tea extracts, alongside particular catechin compounds such as: epicatechin, epigallocatechin gallate and catechin gallate. Such compounds have been recognized as competitive inhibitors of the UGT2B17 enzyme through in vitro studies. Given the concentrations of catechins and testosterone used for these studies reflect those found in vivo, further studies in humans are warranted. Remarkably, the compounds identified as inhibitors were not substrates of the UGT2B17 enzyme, hence providing the potential to investigate the effect of other food substances containing catechins. Popular alcohol beverages such as red wine or cider are two of many substances containing catechins that could be an area for future investigation (Jenkinson et al., 2012b). Previous studies carried out by Park et al. (2007) confirmed the association between increased levels of circulating androgens and the risk of PCa. On this basis, the potential association between $\mathrm{PCa}$ risk and diet can also be suggested from the study carried out by Jenkinson et al. (2012a), whereby the inhibitory effects exerted by components of white and green tea extracts on the UGT2B17 enzymes, and the resulting potential increase in circulating testosterone levels is an indicator for the possible risk of $\mathrm{PCa}$; however this is yet to be confirmed in vivo. Such assumptions warrant additional studies examining foodstuffs and their components for the inhibitory role against UGT enzymes in the perspective of $\mathrm{PCa}$. The multiple roles of flavonoids in promoting cancer include contrasting effects on the tissue activity of detoxification enzymes, such as UGTs via upregulation or inhibition.

\section{Athletes as More 'At Risk' Population}

Studies investigating the consequences of modulated UGT2B15 and UGT2B17 activity to date have focused on linking PCa to androgen levels, as well as highlighting potential implications for the athletic 
community (Figure 2), mainly involving competitive athletes and bodybuilders. Following the work by Schulze et al., (2008), concerns regarding the accuracy of the current doping testing for testosterone were raised and alternative approaches have been suggested (Kicman and Cowan, 2009; Deshmukh et al., 2010; 2012). More importantly from the public health point of view, athletes who are willing to manipulate the UGT2B enzyme activities in order to evade doping testing may put themselves in health risk beyond the currently know side effects of anabolic steroids (van Amsterdam et al., 2010). In addition to potential renal consequences for testosterone or synthetic anabolic steroid users with altered UGT2B17 activity (Deshmukh et al., 2010), the modulated UGT2B activity may also put sportsmen using testosterone boost to enhance their athletic performance or physical appearance at increased risk for developing PCa. Potential healthcompromising consequences of testosterone and/or synthetic steroid doping may be further aggravated by habitual use of NSAIDS, diet and lifestyle choices.

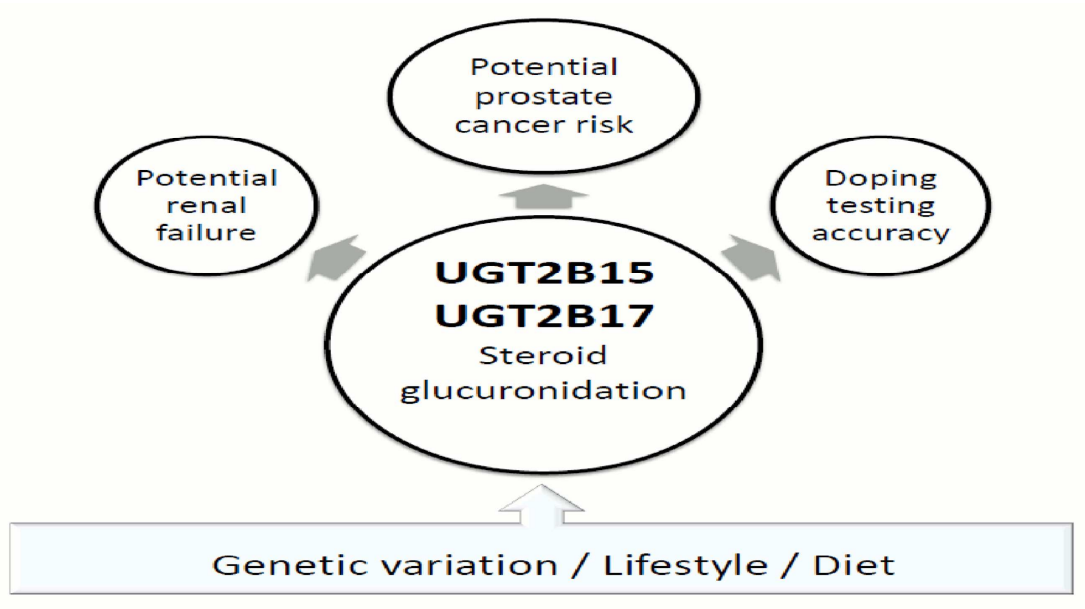

Figure 2: Potential implications of modulated UGT2B15 and UGT2B17 activity.

\section{Conclusions and Future Work}

In this review, the genetic polymorphisms of the UGT2B15 and UGT2B17 enzymes with respect to developing PCa have been discussed as well as the inhibitory effects exerted via UGT2B's on NSAIDs and dietary components. Both the UGT2B15 and UGT2B17 are expressed in the prostate where alterations in the activity may cause fluctuations in the concentration of active androgen levels present. Clinical data obtained during the last decade demonstrated that a reduction in testosterone glucuronidation by genetic alterations of their activity causes an increase in circulating levels of testosterone which has been associated with an increased risk of PCa. Conversely, a reduction in circulating androgen levels was also observed to be implicated with an increased risk. Thus based on the contradictory evidence accumulated, the consequence of UGT2B15 and UGT2B17 genetic polymorphisms remains inconclusive. In addition, a significant difference between the different ethnic minorities in the distribution of these polymorphisms was observed. Whether such genotypic differences constitute a greater risk of $\mathrm{PCa}$ amongst the ethnicities is yet to be determined. Furthermore, the assessment of the inhibitory effects of NSAIDs (diclofenac and ibuprofen) and foodstuffs brings to light the potential external influences that can affect the risk of PCa. However, the studies that confirmed such inhibitory effects were not carried out in the context of PCa. This creates a potential for future research where the effects of such inhibitory components on UGT2B enzymes can be assessed with regards to the risk of $\mathrm{PCa}$. 


\section{References}

Barbier, O. \& Belanger, A. (2008). "Inactivation of Androgens by UDPGlucuronosyltransferases in the Human Prostate," Best Practice and Research Clinical Endrocrinology and Metabolism, 22 (2) 259-270.

Barbier, O., Lapointe, H., El Alfy, M., Hum, D. W. \& Belanger, A. (2000). "Cellular Localization of Uridine Diphosphoglucuronosyltransferase 2B Enzymes in the Human Prostate by In Situ Hybridization and Immunochemistry," Journal of Clinical Endocrinology and Metabolism, 85 (12) 4819-4826.

Bao, B. Y., Chuang, B. F., Wang, Q., Sartor, O., Balk, S. P., Brown, M., Kantoff, P. W. \& Lee, G. S. (2008). "Androgen Receptor Mediates the Expression of UDPGlucuronostltransferase 2B15 and B17 Genes," Prostate, 68 (8) 839-848.

Boehm, K., Borrelli, F., Ernst, E., Habacher, G., Hung, S. K., Milazzo, S. \& Horneber, M. (2009). "Green Tea (Camellia sinensis) for the Prevention of Cancer," Cochrane Database of Systematic Reviews, 3 CD005004.

Bowalgaha, K., Elliot, D. J., Mackenzie, P. I., Knights, K. M. \& Miners, J. O. (2007). "The Glucuronidation of Delta4-3-Keto C19- and C21- Hydroxysteroids by Human Liver Microsomal and Recombinant UDPGlucuronosyltransferase (Ugts): 6-Alpha And 21-Hydroxyprogesterone are Selective Substrates for UGT2B7," Drug Metabolism and Disposition, 35 (3) 363-370.

Brasky, T. M., Kristal, A. R., Navarro, S. L., Lampe, J. W., Peters, U., Patterson, R. E. \& White, E. (2011). "Specialty Supplements and Prostate Cancer Risk in the Vitamins and Lifestyle (VITAL) Cohort," Nutrition and Cancer, 63 (4) 573-582.

Chouinard, S., Barbier, O. \& Belanger, A. (2007). "UDP-glucuronosyltransferase 2B15 (UGT2B15) and UGT2B17 Enzymes are Major Determinants of the Androgen Response in Prostate Cancer LNCaP Cells," Journal of Biological Chemistry, 282 (46) 33466-33474.
Crawford, E. D. (2003). "Epidemiology of Prostate Cancer," Urology, 62 (6 Suppl 1) 312.

Cunningham, J. M., Hebbring, S. J., McDonnell, S. K., Cicek, M. S., Christensen, G. B., Wang, L., Jacobsen, S. J., Cerhan, J. R., Blute, M. L., Schaid, D. J. \& Thibodeau, S. N. (2007). "Evaluation of Genetic Variations in the Androgen and Estrogen Metabolic Pathways as Risk Factors for Sporadic and Familial Prostate Cancer," Cancer Epidemiology, Biomarkers and Prevention, 16 (5) 969-978.

Deshmukh, N., Hussain, I., Barker, J., Petroczi, A. \& Naughton, D. P. (2010). "Analysis of Anabolic Steroids in Human Hair Using LC-MS/MS," Steroids, 75 (10) 710-714.

Deshmukh, N. I. K., Barker, J., Petroczi, A. \& Naughton, D. P. (2012). "Detection of Testosterone and Epitestosterone in Human Hair Using Liquid Chromatography Tandem Mass Spectrometry," Journal of Pharmaceutical and Biomedical Analysis, 67-68 154-158.

Eichhorn, T., Greten, H. J. \& Efferth, T. (2011). "Self-medication with Nutritional Supplements and Herbal Over-The-Counter Products," Natural Products and Bioprospecting, 1 (2) 62-67.

Erichsen, T. J., Ehmer, U., Kalthoff, S., Lankisch, T. O., Muller, T. M., Munzel, P. A., Manns, M. P. \& Stassburg, C. P. (2008). "Genetic Variability of Aryl Hydrocarbon Receptor (Ahr)-Mediated Regulation of the Human UDP Glucuronosyltransferase (UGT) 1A4 Gene," Toxicology and Applied Pharmacology, 230 (2) 252-260.

Gallagher, C. J., Balliet, R. M., Sun, D., Chen, G. \& Lazarus, P. (2010). "Sex Differences in UDP-Glucuronosyltransferase 2B17 Expression and Activity," Drug Metabolism and Disposition, 38 (12) 2204-2209.

Gallagher, C. J., Kadlubar, F. F., Muscat, J. E., Ambrosone, C. B., Lang, N. P. \& Lazarus, P. (2007). "The UGT2B17 Gene Deletion Polymorphism and Risk of Prostate Cancer. A Case-Control Study in Caucasians," Cancer Detection and Prevention, 31 (4) 310-315. 
Gregory, P. A., Lewinsky, R. H., GardnerStephen, D. A. \& Mackenzie, P. I. (2004). "Regulation of UDP Glucuronosyltransferase in the Gastrointestinal Tract," Toxicology and Applied Pharmacology, 199 (3) 354-363.

Gronberg, H. (2003). "Prostate Cancer Epidemiology," Lancet, 361 (9360) 859864.

Gsur, A., Preyer M., Haidinger, G., Schatzl, G., Madersbacher, S., Marberger, M., Vutuc, C. \& Micksche, M. (2002). "A Polymorphism in the UDPGlucuronosyltransferase 2B15 Gene (D85Y) is Not Associated with Prostate Cancer Risk," Cancer Epidemiology, Biomarkers and Prevention, 11 (5) 497-498.

Guillemette, C. (2003). "Pharmacogenomics of Human UDP-Glucuronosyltransferase Enzymes," Pharmacogenomics Journal, 3 (3) 136-158.

Hajdinjak, T. \& Zagradisnik, B. (2004). "Prostate Cancer and Polymorphism D85Y in Gene Dihydrotestosterone Degrading Enzyme UGT2B15: Frequency of DD Homozygous Increases with Gleason Score," Prostate, 59 (4) 436-439.

Havlikova, H., Hill, M., Hampl, R. \& Starka, L. (2002). "Sex- and Age-Related Changes in Epitestosterone in Relation to Pregnenolone Sulfate and Testosterone in Normal Subjects," Journal of Clinical Endocrinology and Metabolism, 87 (5) 2225-2231.

Jakobsson, J., Ekstrom, L., Inotsume, N., Garle, M., Lorentzon, M., Ohlsson, C., Roh, H.- K., Carlstrom, K. \& Rane, A. (2006). "Large Differences in Testosterone Excretion in Korean and Swedish Men are Strongly Associated with a UDPGlucuronosyl Transferase 2B17 Polymorphism," Journal of Clinical Endocrinology, 91 (2) 687-693.

Jenkinson, C., Petroczi, A., Barker, J. \& Naughton, D. P. (2012a). "Dietary Green and White Teas Suppress UDPGlucuronosyltransferase UGT2B17 Mediated Testosterone Glucuronidation," Steroids, 77 (6) 691-695.
Jenkinson, C., Petroczi, A. \& Naughton, D. P. (2012b). "Red Wine and Component Flavonoids Inhibit UGT2B17 in Vitro," Nutrition Journal, 11 (67).

Karypidis, A. H., Olsson, M., Andersson, S. O., Rane, A. \& Ekstrom, L. (2008). "Deletion Polymorphism of the UGT2B17 Gene is Associated with Increased Risk for Prostate Cancer and Correlated to Gene Expression in the Prostate," Pharmacogenomics Journal, 8 (2) 147-151.

Kicman, A. T. \& Cowan, D. A. (2009). "Subject-based Profiling for the Detection of Testosterone Administration in Sport," Drug Testing and Analysis, 1 (1) 22-24.

Lampe, J. W., Bigler, J., Bush, A. C. \& Potter, J. D. (2000). "Prevalence of Polymorphisms in the Human UDP-Glucuronosyltransferase 2B family: UGT2B4 (D458E), UGT2B7 (H268Y), and UGT2B15 (D85Y)," Cancer Epidemiology, Biomarkers and Prevention, 9 (3) 329-333.

Lazarus, P., Zheng, Y., Runkle, A. E., Muscat, J. E. \& Wiener, D. (2005). "Genotype Phenotype Correlation between the Polymorphic UGT2B17 Gene Deletion and NNAL Glucuronidation Activities in Human Liver Microsomes," Pharmacogenetics and Genomics, 15 (11) 769-778.

Lewis, J. E., Soler-Vilá, H., Clark, P. E., Kresty, L. A., Allen, G. O. \& Hu, J. J. (2009). "Intake of Plant Foods and Associated Nutrients in Prostate Cancer Risk," Nutrition and Cancer, 61 (2) 216-224.

Ma, R. W. L. \& Chapman, K. (2009). "A Systematic Review of the Effect of Diet in Prostate Cancer Prevention and Treatment," Journal of Human Nutrition and Dietetics, 22 (3) 187-199.

Mackenzie, P. I., Walter-Bock, K., Burchell, B., Guillemette, C., Ikushiro, S. I., Iyanagi, T., Miners, J., Owens, I. S. \& Nebert, D. W. (2005). "Nomenclature Update for Mammalian UDP Glucuronosyltransferase (UGT) Gene Superfamily," Pharmacogenetics and Genomics, 15 (10) 677-685. 
MacLeod, S. L., Nowell, S., Plaxco, J. \& Lang, N. P. (2000). "An Allele- Specific Polymerase in the Human UDPGlucuronosyltransferase 2B15 Gene in a Case-Control Study of Prostate Cancer," Annals of Surgical Oncology, 7 (10) 777782.

Miners, J. O., McKinnon, R. A. \& Mackenzie, P. I. (2002). "Genetic Polymorphisms of UDP-Glucuronosyltransferase and their Functional Significance," Toxicology, 181182 453-456.

Miners, J. O., Paul A. P. A., Sorich, M. J., McKinnon, R. A. \& Mackenzie, P. I. (2004). "Predicting Human Drug Glucoronidation Parameters. Application of in Vitro and In Silico Modeling Approaches," Annual Review of Pharmacological Toxicology, 44 $1-25$.

Mononen, N. \& Schleutker, J. (2009). "Polymorphisms in Genes Involved in Androgen Pathways as Risk Factors for Prostate Cancer," Journal of Urology, 181 (4) 1541-1549.

Moon, Y. J., Wang, X. \& Morris, M. E. (2006). "Dietary Flavonoids: Effects on Xenobiotic and Carcinogenic Metabolism," Toxicology in Vitro, 20 (2) 187-210.

Neuhouser, M. L. \& Rock, C. L. (2010). "Dietary Supplements and Cancer Risk: Epidemiologic Research and Recommendations," in Preventive Nutrition, the Comprehensive Guide for Health Professionals, (4th Ed) 219-246. Editors: Bendich, A. and Deckelbaum, R. J., Springer, New York/Heidelberg.

Okugi, H., Nakazato, H. \& Matsui, H. (2006). "Association of the Polymorphisms of Genes Involved in Androgen Metabolism and Signalling Pathways with Familial Prostate Cancer Risk in Japanese Population," Cancer Detection and Prevention, 30 (3) 262-268.

Olsson, M., Lindstrom, S., Haggkvist, B., Adami, H. O., Balter, K., Stattin, P., Ask, B., Rane, A., Ekstrom, L. \& Gronberg, H. (2008). "The UGT2B17 Gene Deletion is Not Associated with Prostate Cancer Risk," Prostate, 68 (5) 571-575.
Park, J., Chen, L., Ratnashinge, L., Sellers, T. A., Tanner, J.- P., Lee, J.- H., Dossett, N., Lang, N., Kadlubar, F. F., Ambrosone, C. B., Zachariah, B., Heysek, R. V., Patterson, S. \& Pow-Sang, J. (2006). "Deletion Polymorphism of UDPGlucuronosyltransferase 2B17 and Risk of Prostate Cancer in African American and Caucasian Men," Cancer Epidemiology, Biomarkers and Prevention, 15 (8) 14731478.

Park, J., Chen, L., Shade, K., Lazarus, P., Seigne, J., Patterson, S., Helal, M. \& PowSang, J. (2004). "Asp85Tyr Polymorphism in the UDP-Glucuronosyltransferase (UGT) 2B15 Gene and the Risk of Prostate Cancer," Journal of Urology, 171 (6 Pt 1) 2484-2488.

Park, J. Y., Tanner, J. P., Sellers, T. A., Huang, Y., Stevens, C. K., Dossett, N., Shankar, R. A., Zachariah, B., Heysek, R. \& Pow-sang, J. (2007). "Association between Polymorphisms in HSD3B1 and UGT2B17 and Prostate Cancer Risk," Urology, 70 (3) 374-379.

Ritter, J. K. (2000). "Roles of glucuronidation and UDPglucuronosyltransferases in Xenobiotic Bioactivation Reactions," ChemicoBiological Interactions, 129 (1-2) 171-193.

Schatzl, G., Madersbacher, S., Haitel, A., Gsur, A., Preyer, M., Haidinger, G., Gassner, C., Ochsner, M. \& Marberger, M. (2003). "Associations of Serum Testosterone with Microvessel Density, Androgen Receptor Density and Androgen Receptor Gene Polymorphism in Prostate Cancer," Journal of Urology, 169 (4) 1312-1315.

Schleutker, J. (2011). "Polymorphisms in Androgen Signalling Pathway Predisposing to Prostate Cancer," Molecular and Cellular Endocrinology, 360 (1-2) 25-37.

Schulze, J. J., Lundmark, J., Garle, M., Skilving, I., Ekström L. \& Rane, A. (2008). "Doping Test Results Dependent on Genotype of Uridine DiphosphoGlucuronosyl Transferase 2B17, the Major Enzyme for Testosterone Glucuronidation," Journal of Clinical Endocrinology and Metabolism, 93 (7) 2500-2506. 
Sten, T., Bichlmaier, I., Kuuranne, T., Leinonen, A., Yli-Kauhaluoma, J. \& Finel, M. (2009a). "UDPglucuronosyltransferases (UGTs) 2B7 and UGT2B17 Display Converse Specificity in Testosterone and Epitestosterone Glucuronidation, Whereas UGT2A1 Conjugates both Androgens Similarly," Drug Metabolism and Disposition, 37 (2) 417-423.

Sten, T., Finel, M., Ask, B., Rane, A. \& Ekstrom, L. (2009b). "Non-steroidal AntiInflammatory Drugs Interact with Testosterone Glucuronidation," Steroids, 74 (12) 971-977.

Terakura, S., Murata, M., Nishida, T., Emi, N., Akatsuka, Y., Riddell, S. R., Morishima, Y., Kodera, Y. \& Naoe, T. (2005). "A UGT2B17positive Donor is a Risk Factor for Higher Transplant-Related Mortality and Lower Survival after Bone Marrow Transplantation," Journal of Haematology,129 (2) 221-228.

Timbrell, J. A. (2000). Principles of Biochemical Toxicology, (3rd ed). London: Taylor \& Francis.

Turgeon, D., Carrier, J.- S., Levesques, E., Hum, D. W. \& Belanger, A. (2001). "Relative Enzymatic Activity, Protein Stabilty, and Tissue Distribution of Human SteroidMetabolizing UGT2B Subfamily Members," Endocrinology, 142 (2) 778-787.

Turgeon, D., Chouinard, S., Belanger, P., Picard, S., Labbe, J.- F. \& Borgeat, P. (2003). "Glucuronidation of Arachidonic and Linoleic Acid Metabolites by Human UDPGlucuronosyltransferases," Journal of Lipid Research, 44 (6) 1182-1191.

van Amsterdam, J., Opperhuizen, A. \& Hartgens, F. (2010). "Adverse Health Effects of Anabolic-Androgenic Steroids," Regulatory Toxicology and Pharmacology, 57 (1) 117-123.
Wilson, W., Villena, F. P. M., Lyn-Cook, B. D., Chatterjee, P. K., Bell, T. A., Detwiler, D. A., Gilmore, R. C., Valladeras, I. C., Wright, C. C., Threadgill, D. W. \& Grant, D. J. (2004). "Characterization of a Common Deletion Polymorphism of the UGT2B17 Gene Linked to UGT2B15," Genomics, 84 (4) 707 714.

Wolk, A. (2005). "Diet, Lifestyle and Risk of Prostate Cancer," Acta Oncologica, 44 (3) 271-281. 